\title{
Care in pediatric oncology: a cross-sectional analysis of the quality of life of nursing professionals
}

\author{
O cuidado na oncologia pediátrica: análise transversal da qualidade de vida de profissionais de enfermagem
}

Atención en oncología pediátrica: análisis transversal de la calidad de vida de profesionales en enfermería

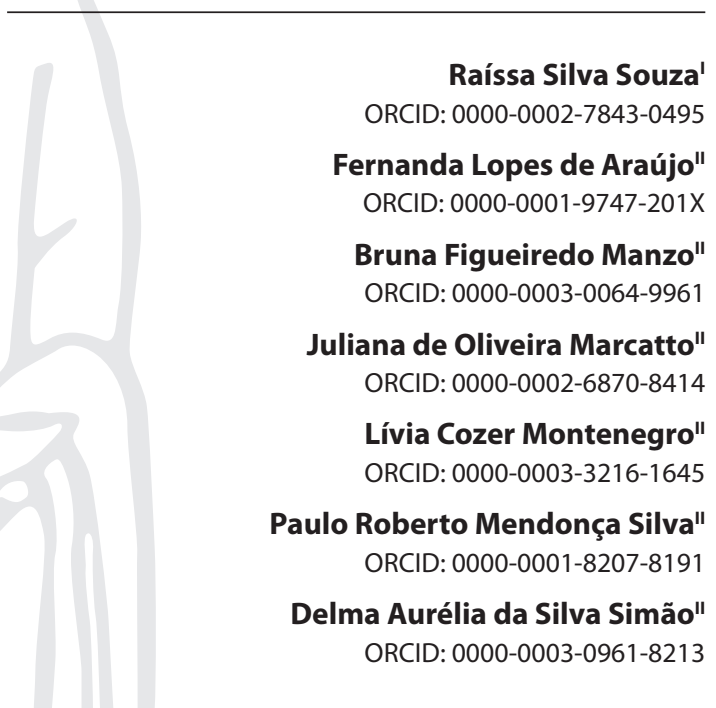

'Universidade Federal de São João del-Rei. Divinópolis, Minas Gerais, Brazil.

"Universidade Federal de Minas Gerais. Belo Horizonte, Minas Gerais, Brazil.

How to cite this article: Souza RS, Araújo FL, Manzo BF, Marcatto JO, Montenegro LC, Silva PRM, et al. Care in pediatric oncology: a cross-sectional analysis of the quality of life of nursing professionals.

Rev Bras Enferm. 2020;73(Suppl 6):e20190639. doi: http://dx.doi.org/10.1590/0034-7167-2019-0639

\section{Corresponding author:}

Delma Aurélia da Silva Simão E-mail:enfdelma@yahoo.com.br

EDITOR IN CHIEF: Antonio José de Almeida Filho ASSOCIATE EDITOR: Ana Fátima Fernandes

\section{ABSTRACT}

Objectives: to assess and correlate sociodemographic and work variables with the quality of life $(\mathrm{QoL})$ of nursing professionals who work with children and adolescents with cancer. Methods: a cross-sectional, analytical, correlational study with 123 volunteers from a public hospital. Sociodemographic characterization questionnaire and WHOQOL-Bref have been used. Results: "sex" ( $p=0.017)$, "work shift" $(p=0.022)$, "employment relationship" $(p=0.049)$ "having children" $(p=0.002)$, "work sector" ( $p=0.047)$, "work shift" $(p=0.007)$ and "employment relationship" $(p=0.040)$ had worse quality of life. "Job duty length" $(p=0.027)$ and "years of study" $(p=0.001)$ and, conversely, "age" $(p=0.004)$ and "job tenure" $(p=0.001)$ were positively correlated with quality of life domains. Conclusions: most professionals rated the overall quality of life as "good". Sociodemographic and work characteristics are associated with worse quality of life. The more years of study and the better job duty length the better the quality of life. Descriptors: Quality of Life; Nursing; Child; Adolescent; Cancer.

\section{RESUMO}

Objetivos: avaliar e correlacionar variáveis sociodemográficas e laborais com a qualidade de vida dos profissionais de enfermagem que atuam com crianças e adolescentes com câncer. Métodos: estudo transversal, analítico, correlacional, com 123 voluntários de um hospital público. Utilizou-se questionário de caracterização sociodemográfica e o WHOQOL-Bref. Resultados: "sexo" $(p=0,017)$, "turno de trabalho" $(p=0,022)$, "vínculo empregatício" $(p=0,049)$ "possuir filhos" $(p=0,002)$, "setor de trabalho" $(p=0,047)$, "turno de trabalho" $(p=0,007)$ e "vínculo empregatício" $(p=0,040)$ associaram-se com pior qualidade de vida. Correlacionaram-se positivamente aos domínios da qualidade de vida "tempo na função" $(p=0,027)$ e "anos de estudo" ( $p=0,001)$, e, de forma inversa, "idade" $(p=0,004)$ e "tempo de profissão" $(p=0,001)$. Conclusões: a maioria dos profissionais avaliou a qualidade de vida global como "boa". Características sociodemográficas e laborais se associam com pior qualidade de vida. Quanto mais anos de estudo e mais tempo na função, melhor é a qualidade de vida.

Descritores: Qualidade de Vida; Enfermagem; Criança; Adolescente; Câncer.

\section{RESUMEN}

Objetivos: evaluar y correlacionar variables sociodemográficas y laborales con la calidad de vida (CV) de los profesionales de enfermería que trabajan con niños y adolescentes con cáncer. Métodos: estudio transversal, analítico, correlacional con 123 voluntarios de un hospital público. Se utilizó un cuestionario de caracterización sociodemográfica y el WHOQOLBref. Resultados: "sexo" ( $p=0,017)$, "turno de trabajo" $(p=0,022)$, "vínculo laboral" $(p=0,049)$ "tener hijos" $(p=0,002)$, "sector laboral" $(p=0,047)$, "turno de trabajo" $(p=0,007)$ y "vínculo laboral" $(p=0,040)$ se asociaron con una peor calidad de vida. Correlación positiva con los dominios de calidad de vida "tiempo en el trabajo" $(p=0,027)$ y "años de estudio" $(p=0,001)$, y viceversa, "edad" $(p=0,004)$ y "tiempo de profesión" $(p=0,001)$. Conclusiones: la mayoría de los profesionales calificaron la calidad de vida global como "buena". Las características sociodemográficas y laborales se asocian a una peor calidad de vida. Cuantos más años de estudio y más tiempo en el trabajo, mejor será la calidad de vida.

Descriptores: Calidad de Vida; Grupo de Enfermería; Niño; Adolescente; Cáncer. 


\section{INTRODUCTION}

The daily practices of health professionals are permeated by a complex and interdependent work process, which requires integrating the actions of several professionals; therefore, it is a collective work. The collective nature of nursing work requires the complementarity of actions by professionals with a technical and higher level who, in addition to sharing the technical dimension of work, need to enable satisfactory human relationships to provide safe, effective, and efficient care, in which possible to produce satisfactory results and according to the populations' health needs ${ }^{(1)}$.

Nursing work in health services requires activities whose essence is care, that is, it is essential that practices are permeated by actions directed towards the other and towards the other. In this care relationship, subjective meetings between those involved, i.e., health professionals and users, become catalysts for expectations. In a meeting between two human beings, moments of intersubjectivities are created, which involve speeches, listening, interpretations, complicity, accountability, hope, and acceptance ${ }^{(2)}$.

In order for such meetings to provide a joint construction of favorable conditions to sort health problems out, it is necessary that the nursing team and users are involved and mutually committed. In a generalized and competitive context, the more humanistic dimensions of care become increasingly challenging, unleashing in professionals a complex network of feelings capable of influencing the work process. Thus, such feelings can often compromise the capacity for reasoning, creativity and problem solving in the field of health.

Especially in caring for children and adolescents with cancer, an area that deals directly or indirectly with significant human issues, linked to life and death, this act is highly complex. The nursing team needs to have competencies that go beyond the technical-scientific sphere. Professionals need to seek strategies that enable them to face from physical overload, to the intense psychological demand that is submitted in their work ${ }^{(3)}$.

The literature points out that routine contact with pain, suffering, terminal life, users' expectations in the health system and the limitations of the care system influence nursing work, negatively impacting quality of life (QoL) of these workers ${ }^{(4)}$.

Quality of Working Life (QWL) refers to a broad understanding of working life conditions, with a view to reconciling the interests of greater productivity by health establishments, and quality at work and satisfaction in family and personal life, by health professionals $\mathrm{s}^{(5-6)}$.

Several factors can be identified that can compromise QWL in the work of nursing professionals in caring for children and adolescents with cancer, such as the type of setting, physical exhaustion, demands for productivity, work shifts, low remuneration, emotional stress, among others ${ }^{(7)}$.

In this sense, it is believed that it is necessary to conduct investigations in this regard, so that it is possible to carry out interventions for professional well-being and satisfaction.

\section{OBJECTIVES}

To assess and correlate sociodemographic and work variables with the quality of life (QoL) of nursing professionals who work with children and adolescents with cancer.

\section{METHODS}

\section{Ethical aspects}

The research project was approved by the Research and Ethics Committee of Universidade Federal de Minas Gerais, under Opinion 1.572.613. Employees who agreed to participate in the survey read and signed the Informed Consent Form (ICF).

\section{Design, period, and place of study}

This is an observational, cross-sectional, descriptive-analytical, quantitative study, in which the Strengthening the Reporting of Observational Studies in Epidemiology (STROBE) was used as a reference ${ }^{(8)}$. Data collection took place between October 2016 and March 2017, in all work shifts in outpatient and hospital units, linked to a public university in the state of Minas Gerais.

\section{Population}

The population considered to carry out this study were all 166 nursing team employees (nurses, nursing technicians and assistants, from chemotherapy outpatient unit, transplant unit, pediatric inpatient unit and pediatric intensive care unit (ICU)).

\section{Inclusion and exclusion criteria}

Professionals who provide direct assistance to children and adolescents with cancer in the units mentioned above were excluded from the study. Professionals who were on vacation, maternity leave or health leave $(n=8)$, who did not accept to participate in the research $(n=9)$ and professionals who work under the Hospital Duty Additional regime $(n=12)$ were excluded. In this type of relationship, professionals do not permanently stay in the unit. Professionals with less than 1 (one) year of experience in pediatric oncology would also be excluded, but none of the volunteers met this criterion. There was also a loss of 14 participants who did not return the questionnaire completed within the pre-established period.

\section{Study protocol}

The data collection instrument was composed of two parts. The first comprised questions regarding the participants' sociodemographic characteristics (26 variables), and the second, WHOQOL-Bref questions (26 items) regarding QoL ${ }^{(9-10)}$.

This instrument was developed by the World Health Organization to assess overall QoL and its physical, psychological, social relations and environmental domains. It was validated in Brazil by researchers from the Department of Psychiatry and Forensic Medicine of the Faculty of Medicine of Universidade Federal do Rio Grande do Sul. The authors identified that the psychometric characteristics of the WHOQOL-Bref, Portuguese version, are similar to those of the study sample that originated the instrument ${ }^{(9-10)}$; therefore, it presents satisfactory characteristics of internal consistency, discriminant validity, criterion validity, concurrent validity and test-retest reliability ${ }^{(10)}$.

Each instrument item has a 5-point Likert scale response option, ranging from "not satisfied" to"very satisfied", the higher the score, the better the QoL. Only items 3, 4 and 26 required recoding of the 
score for calculation purposes ${ }^{(9-10)}$. Such recoding was necessary considering that in the scale these items are presented in an inverse way with respect to the scores when compared to the other items; thus, the lower the score value, the higher the QoL.

QoL, on the other hand, corresponding to each domain of the WHOQOL-Bref, was calculated using the mean of the domain facets, and the value obtained was classified in the following classification: needs to improve ( 1 to 2.9 points), regular ( 3 to 3.9 points), good (4 to 4.9 points), and very good (5 points) ${ }^{(9-10)}$.

The instruments were applied during the interviewees' work period without researcher intervention. Accordingly, questionnaires were distributed to participants and, after completion, were collected.

\section{Analysis of results, and statistics}

The data obtained were entered into the Epidata software (version 3.1) and analyzed in the R software (version 3.2.4). Absolute and relative frequencies were calculated in descriptive analysis of qualitative variables. Meanwhile, measures of position, central tendency and dispersion were calculated in the description of quantitative variables. The Bootstrap method was used to calculate the confidence intervals for the mean of the domains and scores. This method is widely used in making inferences when the probability distribution of the variable of interest is not known. To compare the sector of work with the variables of interest, chi-square and Fisher's exact tests were used for categorical variables and Mann-Whitney U test or Kruskall Wallis tests for numerical variables. Finally, Spearman's correlation of numerical and ordinal variables between QoL domains/scores was performed to understand how much sociodemographic and work data can interfere with the quality of professionals.

\section{RESULTS}

The final sample consisted of 123 professionals, predominantly female $(n=106 ; 86.2 \%)$, married $(n=71 ; 57.3 \%)$, with children $(n=80$; $65.6 \%$ ) and with average age of 38 years (minimum $=20$ years; maximum $=59$ years). Most participants work at the institution as nursing technicians ( $\mathrm{n}=72 ; 58.5 \%$ ), followed by assisting nurses $(n=33 ; 26.8 \%)$, supervising nurses $(n=7 ; 5.7 \%)$, coordinating nurses $(n=3 ; 2.4 \%)$, and nurses who occupy care, supervision and/or coordination positions simultaneously $(n=8 ; 6.5 \%)$. In relation to professional training, more than half $(n=83 ; 68.3 \%)$ of participants had higher education in nursing and the rest $(n=40 ; 32.3 \%)$ had exclusive technical training in nursing. Among graduates, more than half $(n=54 ; 43.5 \%)$ had specialization at latu sensu level, master's degree $(n=10 ; 8.1 \%)$ and doctorate $(n=2 ; 1.6 \%)$. However, the smallest part had specific training in oncology or pediatrics ( $n=25 ; 30.1 \%$ ).

Concerning years of study, the median was 18 years, with a minimum time of 7 years and a maximum of 38 years of study throughout life. As for job tenure, more than half of participants had more than 10 years $(n=74 ; 59.7 \%)$, followed by those with 6 to 10 years $(n=33 ; 26.6 \%)$ and those with less than 5 years $(n=17$; 13.7\%). Most of participants worked at the institution for less than two years $(n=48 ; 40.3 \%)$; however, a considerable portion had a job tenure longer than 10 years $(n=37 ; 31.1 \%)$.

As for sector/unit of activity, more than half of participants worked in pediatric inpatient unit $(n=60 ; 48.4 \%)$. The others were allocated to pediatric ICU ( $n=30 ; 24.2 \%)$, chemotherapy outpatient clinic $(n=21 ; 16.9 \%)$, and transplant unit $(n=13 ; 10.5 \%)$. The most frequent working day among participants was 36 hours per week $(n=56 ; 46.3 \%)$, with the minimum weekly workload per week being 30 hours and the maximum 100 hours.

The majority ( $\mathrm{n}=96 ; 78.0 \%$ ) had only one employment relationship, with a predominance of the CLT (The Consolidation of Labor Laws (Consolidação das Leis do Trabalho) is the decree which governs labor relations in Brazil) regimen ( $n=80 ; 65.0 \%)$, being distributed equally in the afternoon $(n=40 ; 32.5 \%)$ and night shifts $(n=40$; $32.5 \%)$, but with a lower percentage in the morning $(n=29 ; 23.6 \%)$.

The results showed that the majority of participants assessed their overall QoL as "good" or "very good" ( $n=101 ; 80.4 \%)$, with a prevalence $(n=67 ; 54.0 \%)$ of those who said they were "satisfied" with their own health, as can be seen in Table 1.

Table 1 - Distribution of overall quality of life data and by domain of nursing professionals who work with children and adolescents with cancer $(n=123)$, Belo Horizonte, Minas Gerais, Brazil, 2017

\begin{tabular}{|c|c|c|}
\hline Classification & $\mathbf{n}$ & $\%$ \\
\hline \multicolumn{3}{|l|}{ Overall quality of life } \\
\hline \multicolumn{3}{|c|}{ (How do you assess your quality of life?) } \\
\hline Very bad & 1 & 0.8 \\
\hline Bad & 9 & 7.3 \\
\hline Neither bad nor good & 33 & 26.6 \\
\hline Good & 68 & 54.8 \\
\hline Very good & 13 & 10.5 \\
\hline \multicolumn{3}{|c|}{ (How satisfied are you with your health) } \\
\hline Very unsatisfied & 1 & 0.8 \\
\hline Dissatisfied & 15 & 12.1 \\
\hline Neither satisfied nor dissatisfied & 23 & 18.5 \\
\hline Pleased & 67 & 54.0 \\
\hline Very satisfied & 18 & 14.5 \\
\hline \multicolumn{3}{|l|}{ Physical domain } \\
\hline Needs to improve & 14 & 11.3 \\
\hline Regular & 57 & 46.0 \\
\hline Good & 52 & 41.9 \\
\hline Very good & 1 & 0.8 \\
\hline \multicolumn{3}{|l|}{ Psychological domain } \\
\hline Needs to improve & 14 & 11.3 \\
\hline Regular & 61 & 49.2 \\
\hline Good & 47 & 37.9 \\
\hline Very good & 2 & 1.6 \\
\hline \multicolumn{3}{|l|}{ Social relations domain } \\
\hline Needs to improve & 13 & 10.5 \\
\hline Regular & 48 & 38.7 \\
\hline Good & 51 & 41.1 \\
\hline Very good & 12 & 9.7 \\
\hline \multicolumn{3}{|l|}{ Environment domain } \\
\hline Needs to improve & 24 & 19.4 \\
\hline Regular & 84 & 67.7 \\
\hline Good & 16 & 12.9 \\
\hline
\end{tabular}

With regard to the "physical"domain, in which the facets"pain and discomfort","energy and fatigue","'sleep and rest","mobility","'activities of daily living", "dependence on medication or treatment", and "work capacity" are assessed, concentration of assessments was observed in the "regular" ( $n=57 ; 46 \%)$ and "good" ( $n=52 ; 41.9 \%)$ classifications. In the "energy and fatigue" facet, half ( $n=61 ; 51.6 \%)$ answered "medium". Similarly, it was observed that in the "activities of daily living" facet, just over half ( $n=69 ; 56.5 \%)$ answered "average". In the "activities of daily living"facet, almost half ( $\mathrm{n}=58 ; 46.8 \%$ ) answered "medium", and an important portion ( $n=33 ; 26.6 \%)$ answered "very little". 
Similarly, in the"psychological"domain, in which the facets"positive feelings","thinking, learning, memory and concentration","self-esteem", "body image and appearance","negative feelings","spirituality/religion/ personal beliefs", there was also a convergence of assessments in the "regular" $(n=61 ; 49.2 \%)$ and"good" $(n=47 ; 37.9 \%)$ classifications. In this domain, in the "self-esteem" aspect, most participants ( $n=78 ; 63.6 \%)$ reported being "satisfied" or"very satisfied". However, in the"negative feelings" facet, more than half of participants $(n=80 ; 64.5 \%)$ answered "sometimes" or"frequently" ( $n=21,16.9 \%)$.

In the domain "social relationships", in which the "personal relationships", "social support/support" and "sexual activity" facets are assessed, in general, the confluence of assessments was repeated in the "good" ( $n=51 ; 41.1 \%)$ and "regular" $(n=48 ; 38.7 \%)$ classifications. In this domain, the "social relationships" item (how satisfied are you with your personal relationships), most answered "satisfied" ( $n=57 ; 46.8 \%)$ or "very satisfied" $(n=27 ; 21.8 \%)$. Moreover, in the "social support" facet, more than half of participants $(n=62$; 50.4\%) answered to be "satisfied".

In the "environment" domain, in which the aspects "physical security and protection", "environment at home", "financial resources", "health and social care: availability and quality", "opportunity to acquire new information are assessed and skills", "participation and opportunities for recreation/leisure", "physical environment: pollution/noise/traffic/weather", and "transport", participants classified it as"regular" $(n=84 ; 67,7 \%)$ and "needs to improve" $(n=24 ; 19.4 \%)$. In this domain, the "financial resources" aspect, more than half of participants ( $n=69 ; 56.5 \%$ ) answered "average". Still, in the "participation in recreation/leisure opportunities" facet, most employees answered "average" ( $n=58 ; 46.8 \%)$ or "very little" ( $n=33 ; 26.6 \%)$.

When comparing the sociodemographic characteristics and the QoL domains of the nursing professionals, the results indicate that the "sex" $(p=0.017)$, "work shift" $(p=0.022)$ and "employment relationship" $(p=0.049)$ variables were associated with QoL in the "physical" domain. In this case, women, who worked in the morning shift and who had a formal job, had worse QoL scores, as can be seen in Table 2.

Moreover, there was also an association between the variables "having children or not" $(p=0.002)$, "work sector" $(p=0.047)$, "work shift" $(p=0.007)$ and "employment relationship" $(p=0.040)$ with the "environment" domain. In this case, it was evidenced that participants with children, who worked at pediatric inpatient unit in the morning and who worked under CLT regimen had worse QoL rates in the "environment" domain.

The comparison between the numerical and ordinal variables and QoL domains is presented below (Table 3).

A positive and significant correlation can be observed for the "job duty length" $(p=0.027)$ and "years of study" $(p=0.001)$ variables in the "psychological"and "environment" domains, which implies that as job tenure in that duty increases and the more years of study, QoL improves in these domains. Conversely, the "age" $(p=0.004)$ and "job tenure" $(p=0.001)$ variables correlated significantly and inversely with the "environment" domain, i.e., as age and time of profession increase worse is the QoL of nursing professionals.

Table 2 - Comparison of the domains of the quality of life and sociodemographic characteristics of nursing professionals ( $n=123)$, Belo Horizonte, Minas Gerais, Brazil, 2017

\begin{tabular}{|c|c|c|c|c|c|c|c|c|c|c|c|c|}
\hline \multirow{2}{*}{ Variable } & \multicolumn{3}{|c|}{ Physical domain } & \multicolumn{3}{|c|}{ Psychological domain } & \multicolumn{3}{|c|}{ Social relations domain } & \multicolumn{3}{|c|}{ Environment domain } \\
\hline & Mean & S.E. & $p$ value & Mean & S.E. & $p$ value & Mean & S.E. & $p$ value & Mean & S.E. & $p$ value \\
\hline \multicolumn{13}{|l|}{ Sex } \\
\hline Female & 3.69 & 0.06 & \multirow{2}{*}{$0.017^{1}$} & 3.70 & 0.06 & \multirow{2}{*}{$0.109^{1}$} & 3.68 & 0.08 & \multirow{2}{*}{$0.022^{1}$} & 3.34 & 0.05 & \multirow{2}{*}{$0.049^{1}$} \\
\hline Male & 4.08 & 0.13 & & 4.00 & 0.13 & & 4.08 & 0.17 & & 3.62 & 0.11 & \\
\hline \multicolumn{13}{|l|}{ Marital status } \\
\hline Without a partner & 3.82 & 0.07 & \multirow{2}{*}{$0.266^{1}$} & 3.70 & 0.08 & \multirow{2}{*}{$0.721^{1}$} & 3.72 & 0.09 & \multirow{2}{*}{$0.545^{1}$} & 3.43 & 0.06 & \multirow{2}{*}{$0.308^{1}$} \\
\hline With a partner & 3.68 & 0.08 & & 3.77 & 0.07 & & 3.73 & 0.10 & & 3.34 & 0.07 & \\
\hline \multicolumn{13}{|l|}{ Children } \\
\hline No & 3.84 & 0.08 & \multirow{2}{*}{$0.140^{1}$} & 3.71 & 0.09 & \multirow{2}{*}{$0.890^{1}$} & 3.76 & 0.10 & \multirow{2}{*}{$0.985^{1}$} & 3.58 & 0.07 & \multirow{2}{*}{$0.002^{1}$} \\
\hline Yes & 3.70 & 0.07 & & 3.75 & 0.06 & & 3.71 & 0.10 & & 3.29 & 0.06 & \\
\hline \multicolumn{13}{|l|}{ Sector } \\
\hline Pediatric Intensive Care Center & 3.55 & 0.14 & \multirow{4}{*}{$0.038^{2}$} & 3.65 & 0.11 & \multirow{4}{*}{$0.385^{2}$} & 3.70 & 0.13 & \multirow{4}{*}{$0.819^{2}$} & 3.48 & 0.10 & \multirow{4}{*}{$0.047^{2}$} \\
\hline Pediatrics & 3.72 & 0.07 & & 3.72 & 0.07 & & 3.71 & 0.10 & & 3.26 & 0.06 & \\
\hline Chemotherapy & 4.00 & 0.12 & & 3.87 & 0.15 & & 3.75 & 0.20 & & 3.44 & 0.14 & \\
\hline Transplants & 3.86 & 0.13 & & 3.85 & 0.11 & & 3.82 & 0.17 & & 3.59 & 0.13 & \\
\hline \multicolumn{13}{|l|}{ Work shift } \\
\hline Morning & 3.63 & 0.10 & \multirow{4}{*}{$0.044^{2}$} & 3.68 & 0.09 & & 3.57 & 0.13 & & 3.24 & 0.07 & \\
\hline Afternoon & 3.79 & 0.10 & & 3.68 & 0.11 & & 3.67 & 0.14 & & 3.35 & 0.09 & \\
\hline Night & 4.19 & 0.10 & & 4.10 & 0.13 & $0.243^{2}$ & 4.21 & 0.14 & $0.085^{2}$ & 3.91 & 0.14 & $0.007^{2}$ \\
\hline More than one shift & 3.71 & 0.09 & & 3.79 & 0.08 & & 3.83 & 0.11 & & 3.43 & 0.07 & \\
\hline Type of employment & & & & & & & & & & & & \\
\hline CLT & 3.84 & 0.09 & & 3.78 & 0.09 & & 3.68 & 0.13 & 27ר & 3.33 & 0.09 & $000^{2}$ \\
\hline Statutory & 3.72 & 0.07 & & 3.74 & 0.06 & $0.237^{2}$ & 3.76 & 0.08 & $0.128^{2}$ & 3.42 & 0.05 & $0.040^{2}$ \\
\hline Other & 2.50 & 0.10 & $0.045^{2}$ & 3.05 & 0.25 & & 3.15 & 1.15 & & 2.30 & 0.20 & \\
\hline Work regime & & & & & & & & & & & & \\
\hline 30 hours & 3.73 & 0.12 & & 3.68 & 0.13 & & 3.61 & 0.19 & & 3.35 & 0.12 & \\
\hline 36 hours & 3.80 & 0.08 & $0.356^{2}$ & 3.80 & 0.08 & $0.435^{2}$ & 3.70 & 0.10 & $0.720^{2}$ & 3.45 & 0.07 & $0.502^{2}$ \\
\hline Other & 3.66 & 0.10 & & 3.70 & 0.09 & & 3.79 & 0.12 & & 3.31 & 0.08 & \\
\hline Employment relationship & & & & & & & & & & & & \\
\hline Only one & 3.78 & 0.06 & 01651 & 3.76 & 0.06 & 04391 & 3.75 & 0.08 & 04991 & 3.39 & 0.05 & 09511 \\
\hline More than one & 3.61 & 0.11 & 0.165 & 3.66 & 0.10 & $0.439^{\prime}$ & 3.65 & 0.15 & $0.499^{\prime}$ & 3.35 & 0.10 & יו15 0.95 \\
\hline
\end{tabular}


Table 3 - Spearman correlation (rho) between domains/scores and numerical and ordinal variables ( $n=123)$, Belo Horizonte, Minas Gerais, Brazil, 2017

\begin{tabular}{lcccc}
\hline Variables & $\begin{array}{c}\text { Physical } \\
\text { domain } \\
\text { (rho) }\end{array}$ & $\begin{array}{c}\text { Psychological } \\
\text { domain } \\
\text { (rho) }\end{array}$ & $\begin{array}{c}\text { Social } \\
\text { relations } \\
\text { domain } \\
\text { (rho) }\end{array}$ & $\begin{array}{c}\text { Environment } \\
\text { domain } \\
\text { (rho) }\end{array}$ \\
\hline Age & -0.05 & -0.02 & -0.07 & $-0.26(\mathrm{p}=0.004)^{*}$ \\
Years of study & 0.10 & 0.05 & 0.19 & $0.36(\mathrm{p}=0.001)^{*}$ \\
Weekly workload & -0.12 & 0.04 & -0.11 & -0.03 \\
Academic degree & 0.02 & 0.03 & 0.03 & 0.37 \\
Job tenure & -0.03 & 0.05 & -0.01 & $-0.14(\mathrm{p}<001)^{*}$ \\
Job duty length & 0.15 & $0.20(\mathrm{p}=0.027)^{*}$ & 0.11 & 0.06 \\
\hline Note: ${ }^{*} p$ value $<0.05$. & & & &
\end{tabular}

\section{DISCUSSION}

According to sociodemographic characterization, most of participants are women, married, with children, with an average age of 38 years old, graduated at a higher level, but hired for professional practice as nursing technicians. Most of these professionals work 36 hours a week and have worked at their institution for over 10 years. This profile reinforces the historical context of nursing, which predominates the female workforce ${ }^{(6)}$.

Historically, caring has been associated with women, building a social imaginary about nursing, loaded with female stereotypes, whose role and status of the profession are subordinate to the role and status of women ${ }^{(6)}$. According to the Brazilian Nursing Profile Survey, women constitute $85.6 \%$ of the total nursing professionals registered with COFEN (Conselho Federal de Enfermagem - Federal Nursing Council) ${ }^{(11)}$. The feminization of nursing work brings to light the complexity and variety of conditions that interfere in these women's daily lives, as in addition to professional work with a high workload of dedication, they have housework in their daily work, which favors levels moderate to high stress ${ }^{(12)}$. Concerning the hours worked, it is believed that it is directly related to people's QoL, as those who have more free time can practice leisure activities that promote health and well-being.

Despite not having been the object of this study, the comparison between the QoL of mid-level and higher-level nursing professionals is important. The results showed a divergence between the duty performed and professional training. Much of the sample was graduated in nursing but remained in a mid-level position. It is known that from the moment that professionals acquire higher levels of training, they create expectations around prospects for advancing their professional careers, with a consequent increase in satisfaction, autonomy and training to make decisions $^{(13)}$. However, the mismatch between the demands of the labor market and the nursing professional training available, both in quantitative and qualitative terms, has impacted socially and economically on the lives of these professionals, leading many to remain in mid-level positions. This tends to create and reproduce inequalities in opportunities for professionals, favoring the creation of unhealthy work environments.

Despite the fragile work relationships from the point of view of the feminization of work and professional development, participants have been linked to the institution for over 10 years and feel "satisfied" with their QoL and health. A similar result was found recently in another survey that used the same QoL assessment instrument with nurse-midwives in Poland ${ }^{(14)}$.
Job satisfaction consists of feelings linked to various work aspects and represents an indicator of physiological and emotional well-being ${ }^{(15)}$. With regard to the satisfaction of professionals who care for children and adolescents with cancer and their families, the experience of feelings of gratitude and pleasure pertaining to affective bonds, empathy and otherness built during the therapeutic relationship favor well-being perception ${ }^{(16)}$. However, it is known that other factors can influence this issue, such as the existence of adequate working conditions, physical, mental and social security, in addition to the provision of qualifications for carrying out professional activities with safety and good use of personal energy ${ }^{(5)}$.

In the assessment of the "physical" domain of QoL, there was a preponderance of the "regular" overall assessment, with worse scores on the facets related to energy for daily activities, capital for meeting needs and opportunities for leisure activities. It is understood that physical exhaustion associated with carrying out work duties, added to long working hours, shift turnover, shifts during holidays and weekends, irregular meal times, among others, have supported this finding ${ }^{(7)}$. Furthermore, the double working hours practiced by a significant portion of Brazilian women intensify physical and mental exhaustion as well as reducing the time available for leisure activities ${ }^{(15)}$.

Moreover, tension related to the impossibility of participating in social events and social gatherings as well as in moments of strengthening family ties, such as playing with children or putting them to sleep, can contribute to mental disorders that negatively impact in the performance of job duties ${ }^{(12)}$.

With regard to the "psychological" domain, which is also mostly assessed as "regular", the negative feelings facet stood out, with worse assessment. Daily contact with diseases, pain, difficult life situations and sometimes the death of patients under their care can trigger negative feelings that, when not properly managed, culminate in psychological suffering and decreased QoL of nursing professionals ${ }^{(14)}$; this can seriously compromise their mental health ${ }^{(16)}$.

Offering strategies for psychological distress prevention and mitigation, aimed at nursing team professionals in companies, especially those in which the performance with serious diseases such as cancer is preponderant, could create conditions conducive to improving their perception of QoL. Some relevant strategies are experience sharing groups or support groups, individualized listening with psychologists ${ }^{(17)}$ and even complementary therapies such as auriculotherapy, which has already proved effective in reducing stress and improving the $\mathrm{QoL}$ with these professionals ${ }^{(18)}$.

Despite these findings, the participants of this research indicated, in the "psychological" domain, to be satisfied with themselves; this can signal a possible resilient profile of these professionals. Such fact can favor coping with stress at work, in addition to protecting from emotional exhaustion and contributing to the adoption of a positive attitude by nursing professionals both among their peers and with children and adolescents with cancer and their families ${ }^{(15)}$.

Assessment of the "social relations" domain was slightly different, with the prevalence of the "good" classification, with the facets referring to satisfaction with personal relationships and with the support of friends having the best scores. Such findings 
show that, although these professionals experience physical and psychological stress, they feel supported by their network of contacts. Positive interpersonal and social support relationships, both in personal and professional life, provide a feeling of satisfaction with work and life ${ }^{(14)}$.

Moreover, the experience of working in health, regardless of the economic perspective, harmonizes with the elements of daily work and is transformed by the possibility of helping other people in their condition as human beings ${ }^{(2)}$. It is believed that social relation satisfaction is expressed by a complex network of acts, procedures, flows, routines and knowledge, in a process shared among several actors in hospitals ${ }^{(2)}$.

The comparative analyzes indicated a statistically significant association between the "sex" and "having children" sociodemographic variables with worse QoL in the "physical", "social relationships" and "environment" domains. In turn, the work variables associated with worse QoL scores in the "physical" and "environment" domains were "sector of activity", "work shift" and "type of employment". This means that women with children, who work in the morning shift, in oncopediatric hospitalization and pediatric ICU sectors, under CLT regime, have worse QoL. In this regard, it is understood that the double working hours of women, still quite usual in contemporary Brazilian society and all the physical and psychological burdens associated with it, certainly had a negative impact on the participants' perception, especially on the "physical" domain. Furthermore, it is understood that, although childcare is often divided between fathers and mothers, women/mothers end up taking on most of tasks, responsibilities and concerns, experiencing the repercussions in their QoL.

On the other hand, continuous and prolonged contact with children and adolescents with cancer as well as with their families lead nursing professionals to actively participate in the history of these people and, often, to get involved emotionally and to share with them different feelings that ranging from joy for small or big conquests to hopelessness and discouragement, which ends up compromising their $\mathrm{QWL}^{(19)}$. A way that is often used empirically by these professionals to minimize this affective involvement is distancing, which can make care impersonal and less empathic.

Furthermore, characteristics specific to the work process organization of nursing teams in hospital institutions cause accumulation of direct assistance activities with patients in the morning shift, which intensifies professional physical exhaustion. It is believed that a careful redistribution of these activities throughout the day would attenuate the physical exhaustion of professionals who work in the morning, having a positive impact on QoL and assistance in general ${ }^{(20)}$.

It is understood that the influence of the relative legal and economic insecurity, related to the CLT employment relationship, also compromises assessing the "physical" and "environment" domains. This is due to the fear of unemployment and its repercussions and to the demands for productivity and visibility at work, which promotes stress and exacerbates the damage to QoL.

Despite this, the results showed that professionals with higher job tenure and with more years of study have better QoL, specifically in the "psychological" domain. Such fact portrays the presence of positive feelings, the ability to learn, memorize and concentrate, better self-esteem, body image and appearance, greater spirituality/religiosity with less presence of negative feeling $s^{(10)}$. Adaptation to the work sector, service routines and required assistance activities is possible as professionals perform the same duty for a longer time, which also allows creating individual mechanisms to minimize the potential stressors present in the work routine; this makes professionals feeling safer and more confident in providing assistance.

Conversely, it is noted that as job tenure and age of nursing professionals who work with children and adolescents with cancer increases, QoL decreases in the "environment" domain. This domain reflects the perception about the aspects of physical security and protection, home environment, financial resources, health and social care, availability and quality of health and social care, opportunities to acquire new information and skills, opportunities for recreation and leisure, physical environment (pollution/noise/traffic/weather) and transport ${ }^{(10)}$. A study assessed the association between occupational stress and QWL of 309 nursing professionals who worked at a large hospital in the countryside of Bahia State. Through a regression model, the study confirmed that the performance in sectors that provide assistance to highly dependent or critical patients ( $\mathrm{PR}=2.47 ; 95 \% \mathrm{Cl}: 1.18$ 5.19; $\mathrm{p}=0.017)$, in duties considered as "active work" (PR=1.74; $95 \% \mathrm{Cl}: 1.04-2.92 ; \mathrm{p}=0.034)$ and "high demand" $(\mathrm{PR}=.54 ; 95 \% \mathrm{Cl}$ : $1.51-4.27 ; \mathrm{p}<0.001)$ lead to greater dissatisfaction with $\mathrm{QWL}{ }^{(21)}$. It can be said that working with children and adolescents with cancer is similarly working with a highly dependent population due to age and health conditions that demand highly complex actions continuously.

\section{Study limitations}

The present study has limitations, among which are crosssectional design with which it is not possible to draw conclusions about cause and effect relationships between variables. Moreover, it is believed that the option for investigating variables related to participant professional background, such as job tenure, level and type of training of professionals, could have been extended to the time of their performance specifically in cancer and/or pediatric care. Furthermore, as the information collected was self-reported, it is understood that all answers may have been compromised by the participants' interest and attitude.

\section{Contributions to nursing, health, and public policies}

It is understood that this study comprises the knowledge of the elements that influence the QoL of professionals who care for children and adolescents with cancer. This fact may support further interventions with a view to maximizing QoL in the workplace and patient and family care.

\section{CONCLUSIONS}

The QoL of nursing professionals who assist children with cancer at a public university hospital was considered good by most of those investigated. Gender and having children were associated with the QoL of these professionals. Women with 
children had the worst averages in different QoL domains. The work variables that showed an association with QoL were"work sector", "work shift", and "type of employment relationship". Furthermore, the more years of study and the higher job duty length a nursing professional has the better the QoL scores in different domains. However, the age of professionals as well as job tenure were inversely correlated, which indicates that professionals with more job tenure and older have a worse perception of their QoL.

In this regard, it is important and necessary to make adjustments to work routines, in addition to the implementation of prevention and mitigation strategies for different types of suffering, with a view to better QoL.

\section{REFERENCES}

1. Souza IAS, Pereira MO, Oliveira MAF, Pinho PH, Gonçalves MDA. Work process and its impact on mental health nursing professionals. Acta Paul Enferm. 2015;28(5):447-53. doi: 10.1590/1982-0194201500075

2. Seixas CT, Baduy RS, Cruz KT, Bortoletto MSS, Slomp JH, Merhy EE. O vínculo como potência para a produção do cuidado em Saúde: o que usuários-guia nos ensinam. Interface (Botucatu). 2019;23:e170627. doi: 10.1590/interface.170627

3. Alencar AR, Alencar AMPG, Menezes IRA, Kerntopf MR, Ramos AGB, Brito SMO, et al. Emoção e cuidado na assistência à criança com câncer: percepções da equipe de Enfermagem. Rev Cuba Enferm[Internet]. 2015 [cited 2019 Jun 28];30(2):96-107. Available from: http://www. revenfermeria.sld.cu/index.php/enf/article/view/518/88

4. Al-Majid S, Carlson N, Kiyohara M, Faith M, Rakovski C. Assessing the degree of compassion satisfaction and compassion fatigue among critical care, oncology, and charge nurses. J Nurs Adm. 2018;48(6):310-5. doi: 10.1097/NNA.0000000000000620

5. Hipólito MCV, Masson VA, Monteiro MI, Gutierrez GL. Quality of working life: assessment of intervention studies. Rev Bra Enferm. 2017;70(1):178-86. doi: 10.1590/0034-7167-2015-0069

6. Lombardi MR, Campos VP. [Nursing in Brazil and the gender, race/color and social classes in the training of the professional field]. Rev ABET. 2018;17(1):28-46. doi: 10.22478/ufpb.1676-4439.2018v17n1.41162 Portuguese.

7. Freire MN, Costa ER. [Quality of life of nursing professionals in the work environment]. Rev Enferm Contemp. 2016;5(1):151-8. doi: 10.17267/2317-3378rec.v5i1.871 Portuguese.

8. Malta M, Cardoso LO, Bastos FI, Magnanini MMF, Silva, CMFP. Comentários sobre a Iniciativa STROBE. Rev Saúde Pública. 2010;44(3):559-65. doi: 10.1590/S0034-89102010000300021

9. World Health Organization. The Whoqol Group. Programme on Mental Health. WHOQOL-BREF: Introduction, Administration, Scoring and Generic Version of the Assesment. 1996.

10. Fleck MPA, Louzada S, Xavier M, Chachamovich E, Vieira G, Santos L, et al. Application of the Portuguese version of the abbreviated instrument of quality life WHOQOL-bref. Rev Saúde Pública. 2000;34(2):178-83.doi: 10.1590/S0034-89102000000200012

11. Machado MH, Aguiar WF, Lacerda WF, Oliveira E, Lemos W, Wermelinger M, et. al. Relatório final da Pesquisa Perfil da Enfermagem no Brasil: Convênio: FIOCRUZ/COFEN[Internet]. Rio de Janeiro: 28 volumes, 2015. [cited2019Abr 5]. Available from: http://www.cofen.gov.br/perfilenfermagem/

12. Ratochinski CMW, Powlowytsch PWM, Grzelczak MT, Souza WC, Mascarenhas LPG. O estresse em profissionais de enfermagem: uma revisão sistemática. Rev Bras Ciên Saúde. 2016;20(4):341-6. doi: 10.4034/rbcs.2016.20.04.12

13. Oliveira EM, Barbosa RL, Andolhe R, Eiras FRC, Padilha KG. Nursing practice environment and work satisfaction in critical units. Rev Bras Enferm. 2017;70(1):73-80. doi: 10.1590/0034-7167-2016-0211

14. Czekirda M, Jarosz MJ, Chruściel P. Psychosocial aspect of quality of life among working and unemployed nurses and midwives. Ann Agric Environ Med. 2017;24(3):472-6. doi: 10.5604/12321966.1235172.

15. Zavala MOQ, Klijn TP, Carrillo KLS. Quality of life in the work of the nursing staff of public health institutions. Rev Latino-Am Enferm. 2016;24:e2713. doi: 10.1590/1518-8345.1149.2713

16. Rocha DD, Nascimento EC, Raimundo LP, Damasceno AMB, Bondim HFFB. Feelings experienced by nursing professionals in the face of death in neonatal. Mental [Internet]. 2017 [cited 2019 Jun 28];11(21):546-60. Available from: http://pepsic.bvsalud.org/pdf/mental/v11n21/v11n21a15.pdf

17. Freitas PH, Colomé CL, Viero V, Fernandes MNS, Machado KL. Defensive strategies used by nurses in the "EstratégiaSaúde da Família" to cope with distress. Texto Contexto Enferm. 2016;25(4):e3050014. doi: 10.1590/0104-07072016003050014

18. Kurebayashi LFS, Silva MJP. Chinese auriculotherapy to improve quality of life of nursing team. Rev Bras Enferm. 2015;68(1):117-23. doi: 10.1590/0034-7167.2015680116p

19. Delfino CTA,Ferreira WFS, Oliveira EC,Dutra DA. Câncer infantil: atribuições da enfermagem em cuidado paliativo. Rev Saúde Desenvolv[Internet]. 2018[cited 2020 Jun 10];12(10). Available from: https://www.uninter.com/revistasaude/index.php/ saudeDesenvolvimento/article/view/866/497

20. Vidotti V, Ribeiro RP, Galdino MJQ, Martins JT. Burnout Syndrome and shift work among the nursing staff. Rev Latino-Am Enferm. 2018;26:e3022. doi: 10.1590/1518-8345.2550.3022

21. Azevedo BDS, Nery AA, Cardoso JP. Occupational stress and dissatisfaction with quality of work life in nursing. Texto Contexto Enferm[Internet]. 2017 [cited 2020 Jun 10];26(1):e3940015. Available from: https://www.redalyc.org/pdf/714/71449839010.pdf 